\title{
Ownership Concentration and Degree of Compliance with Corporate Governance Best Practices of Public Listed Companies in Sri Lanka
}

\author{
G S Mapitiya, A R Ajward and Samanthi Seneratne
}

\begin{abstract}
This study examines the relationship between ownership concentration and the degree of compliance with corporate governance best practices of public listed companies in Sri Lanka. Firstly, the study examines ownership concentration in terms of ownership types of fifty two companies listed on the Colombo Stock Exchange (CSE) for a five-year period from 2009 to 2013 by focusing on their ultimate ownership. Accordingly, two ownership types- 'closely held' and 'widely held'-were identified. Secondly, to measure the degree of compliance with corporate governance best practices, a Corporate Governance Index was developed incorporating selected governance characteristics pertaining to the board of directors. The study was conducted as a quantitative study based on secondary data collected from annual reports. The study finds that the ownership is concentrated in most of the selected companies with the presence of a controlling shareholder and widely held entities are rare in Sri Lanka as in the case of other Asian countries. Further, the analysis finds that a higher degree of ownership concentration has a significant negative relationship with compliance with corporate governance practices. This indicates that the degree of compliance with corporate governance best practices is significantly lower in closely held companies than in widely held companies. Hence, the study concludes that the degree of ownership concentration in Sri Lankan public listed companies has a significant influence on compliance with the corporate governance practices pertaining to board characteristics.
\end{abstract}

Keywords: Agency Theory, board of directors, closely held, corporate governance, ownership concentration, ownership types, widely held

Gayan S Mapitiya is a Lecturer of the Department of Commerce, Faculty of Management Studies and Commerce, University of Sri Jayewardenepura. E-mail: gmapitiya@gamil.com. (Corresponding author)

A R Ajward, $\boldsymbol{P h D}$ is a Senior Lecturer of the Department of Commerce, Faculty of Management Studies and Commerce, University of Sri Jayewardenepura.

Samanthi Senaratne, $\boldsymbol{P h D}$ is a Professor of the Department of Accounting, Faculty of Management Studies and Commerce, University of Sri Jayewardenepura. 


\section{Introduction}

The importance of corporate governance became very clear with many corporate scandals, failures, frauds and bankruptcies that took place around the world in recent times (Kaur \& Gill 2008). A number of large American, European and Asian companies including Enron, WorldCom, Xerox, Tyco, Adelphia, Global Crossing,Parmalat, European's Enron, Hong Guang Co., LanTian Co., \& Tong Hai Co. collapsed during the financial crises that took place all over the world (Wei and Geng 2008). In the Sri Lankan context, some corporate failures took place in the late 1980s and in the early 1990s through to 2008, especially in the Banking and Finance Industry (Heenetigala 2011). The lack of sound corporate governance practices has been identified as a main reason for these crises (Haat, Rahman \& Mahenthiran 2008). This led to issues of corporate governance practices receiving considerable attention from the public, academics, policy makers and regulators recently as it is identified as a key factor that contributes to the success of companies and the economic health of society (Klein, Shapiro \& Young 2005, Kaur \& Gill 2008, Azim 2012). Further, Barton (2007) finds that investors are willing to pay a premium of 25 percent for a well-governed company. Therefore, the need for more effective monitoring mechanisms to improve corporate governance systems became a much needed requirement (Cazurra \& Aguilera 2004).

Shareholders are the owners of companies (Monks \& Minow 1995) and they are of different types (Connelly et al. 2010). For instace, La Porta, De Silanes and Shleifer (1999) identify different ownership types in companies around the world that include individual, family, state and widely held. Further, Gollakota and Gupta (2006) identify family, professional, government, foreign and public as different types of ownership of companies. Most of the companies in Anglo-Saxon countries like the USA and the UK are widely held. On the other hand, most companies in Asian countries are closely held by individuals and families (Claessens \& Fan 2003, Wei \& Geng 2008). These different ownership types result in different corporate governance systems in companies (Mollah, Farooque \& Karim 2012). Hence, ownership is considered an important determinant of the governance system of a company (Klein, Shapiro \& Young 2005).

Corporate governance issues arise from the separation of the ownership and the management of corporate entities (Jensen 1998). The widely held ownership structure of large companies in western countries such as the USA and the UK is considered as the origin of the conflict between the owners and the managers, which is known as the agency conflict (La Porta, Shleifer \& Da Silanes 1999). This view was initially derived from the studies of Berle and Means (1932) and was developed further by Jensen and Meckling (1976). However, the 
degree of conflict between the owners and the managers varies according to the degree of ownership concentration of the companies. Owners attempt to impose more formal monitoring mechanisms to control managers and avoid a conflict of interest between the owners and the managers (Jensen 1989, Mayer 1997). Mollah, Farooque and Karim (2012) stated that the corporate governance system varied according to the ownership structure of the corporate sector. In the Sri Lankan context, a previous study by Senaratne and Gunaratne (2008) found that ownership is concentrated in most Sri Lankan listed companies with the presence of a controlling shareholder and widely held entities are rare in the Sri Lankan context as in most other Asian countries. This study also reveals that these controlling shareholders make a significant impact on the manner in which the companies are governed in Sri Lanka. Extending the Senaratne and Gunaratne study, the current study addresses the issue of whether the degree of ownership concentration in terms of ownership type influences compliance with corporate governance best practices of Sri Lankan public listed companies. Accordingly, the main objective of the current study is to examine the relationship between ownership concentration in terms of ownership types and the degree of compliance with corporate governance best practices pertaining to the board of directors in public listed companies in Sri Lanka.

The next section of the paper discusses the literature related to corporate governance, ownership types and the agency theory. Then the hypotheses are developed and the theoretical framework is presented. Next, the methodology is outlined after which the analysis and discussion of findings are presented. This is followed by the conclusions of the study with implications and suggestions for future research.

\section{Literature Review}

\section{Corporate Governance}

The concept of corporate governance is defined in many ways in the literature. However, it is commonly agreed in these definitions that ensuring the financial health of a corporate entity is important. Shleifer and Vishny (1997) define corporate governance as the ways in which suppliers of finance to companies assure themselves of getting a return on their investment. On the other hand, the Cadbury Committee defines corporate governance as 'the system by which companies are directed and controlled' (Cadbury 1992, p.14). In addition, Bokpin, Isshaq and Otchere (2011) report that corporate governance is a system of mechanisms that serves to ensure that shareholder wealth is maximized and it does so via several methods geared towards enforcing the stewardship responsibilities of managers. As for the importance of the concept of corporate governance, the extant literature indicates that it is an essential 
part of risk management for shareholders (Charkham \& Simpson 1999). Further, corporate governance has not only significant implications for the financial stability and performance of companies (Rezaee 2009) but also wider implications for the economic development and social well-being of a country (Clarke 2004). More importantly, corporate governance becomes a multifaceted subject due to the complexities in the globalization of business operations (Monks \& Minow 1995). Thus, researchers argue that corporate governance is a vital mechanism for an organization to survive in a competitive and turbulent business environment and also to achieve its long-term goals. According to Clarke (2004), corporate governance involves the exercise of power to direct and control companies. Many studies have cited the failure of corporate governance as one of the main causes of financial crises around the world (Bokpin 2013). Moreover, corporate governance is of critical importance to investors, insurers, regulators, creditors, customers, employees and other stakeholders of companies (Haat, Rahman \& Mahenthiran 2008). In addition, Mollah, Farooque and Karim (2012) reported that corporate governance mechanisms are the market, institution and legal settings that protect outside investors from the opportunistic behaviour of managers or controlling shareholders.

Good corporate governance is accepted as vital for achieving the millennium development goals and sustainable economic growth (Mwanja et al. 2014). Cazurra and Aguilera (2004) state that good governance practices consider the issues related to the role, composition, remuneration, selection and removalof the board of directors, relationships with shareholders and top management, auditing and information disclosure. Clarke (2014) states that boards of directors are an essential part of the DNA of corporations, and corporate governance is a vital means of fulfilling the strategic potential of corporations. In addition, Clarke (2014) states that in the absence of such protection, asymmetries of information and difficulties of monitoring suffered by outside investors enable managers to misallocate and expropriate corporate resources, often at the expense of minority investors and of long-term firm performance. Most of the early definitions of corporate governance explain corporate governance as a system utilized to shield investors' interests (Tuan 2014).

Corporate governance codes have beenintroduced from time to time by many countries to articulate best practices on governance. The first code of corporate governance was introduced in the late 1970s in the USA emphasizing the role of the board of directors (Cazurra \& Aguilera 2004). However, the Cadbury Report issued in the UK in 1992, which is the flagship guideline for corporate governance practices (Stiles \& Taylor 1993), focuses on the financial aspects of corporate governance (Cazurra \& Aguilera 2004). The first code of best practices on corporate governance was issued in Sri Lanka in 1997 by the Institute of Chartered 
Accountants of Sri Lanka (CA Sri Lanka). This was revised several times and the latest code was issued jointly by the CA Sri Lanka and the Securities and Exchange Commission (SEC) of Sri Lanka in 2013. These Sri Lankan codes are also largely influenced by the codes of best practice developed in the UK.

\section{Ownership types}

Firms may be owned by different types of investors (Connelly et al. 2010) and they act differently in governing a company. The widely held ownership structure of large firms in Anglo-Saxon countries is known as the root cause of agency conflicts in the firm (La Porta et al. 2000). Thus, the agency theory suggests that the presence of a large shareholder can lead to better performance because it reduces agency problems between the owners and the managers (Jensen \& Meckling 1976). La Porta et al. (2000) divide firms into two categories as widely held and closely held with a controlling owner, based on an analysis of ultimate owners in selected 27 wealthy economies. Similarly, Klein, Shapiro and Young (2005) classify companies as widely held and not widely held, based on the voting rights of shareholders. La Porta et al. (2000) also report that several other studies (Eisenberg 1976, Demsetz 1983, Demsetz \& Lehn 1985, Shleifer \& Vishny 1986, Morck, Shleifer \& Vishny 1997) show that even among the largest American firms, there is a modest concentration of ownership.

Recent research has documented large differences among countries regarding ownership concentration in publicly traded firms (La Porta et al. 2000). Large shareholdings or majority ownership is relatively uncommon in the USA and the UK but in most European countries as well as in Latin America, Southeast Asia and Africa, firms are typically controlled by families (Wei \& Geng 2008). La Porta et al. (2000) also cited studies of other rich nations that reveal a more significant concentration of ownership, for example, Germany (Edwards \& Fischer1994, Franks \& Mayer 1994, Gorton \& Schmid 1996), Japan (Prowse 1992, Berglof \& Perotti 1994), Italy (Barca 1995) and seven OECD countries (European Corporate Governance Network 1997). In developing economies, ownership is also heavily concentrated (La Porta et al. 2000). The case is no different in Sri Lanka as in most Sri Lankan listed companies ownership is concentrated in the hands of a controlling shareholder, who enjoys much higher controlling rights over cash flow and widely held entities are rare as in most other Asian countries (Senaratne \& Gunaratne 2008). 


\section{Agency Theory}

The principal-agent conflict identified by Jensen and Meckling (1976) is the foundation of corporate governance studies (Jensen 1998). Indeed, the crux of the principal-agent model is the separation of ownership and control of companies and it is also the starting point of most discussions on corporate governance (Shleifer \& Vishny 1997). Fama and Jensen (1983) state that the separation of decision-making and risk-bearing is more common in large companies compared to other closely held companies. Furthermore, Lubatkin et al. (2005) documented that agency theory discusses the issues that arise when principals assign decision-making powers to agents in any organization. Further, they report that managers (agents) involved in day-to-day operations can hide information from widely spread owners (principals) who do not have access to this information. Therefore, owners are compelled to invest in monitoring mechanisms to avoid the opportunistic behaviour of managers (Hart 1995). It is obvious that unmonitored managers will attempt to achieve their own goals rather than those of owners (Greenwood, Deephouseand \& Li 2007). Therefore, effective corporate governance practices prevent the conflicts of interest between agents (managers) and principals (owners) by improving the use of corporate resources for the maximization of owners' returns (Love 2010).

The current study is grounded on the literature on corporate governance, ownership concentration in terms of ownership types and agency theory discussed in this section. The next section presents the conceptual framework of the current study and the related hypothesis.

\section{Conceptual Framework and Hypothesis}

As reported by Shleifer and Vishny (1997), most of the past studies on ownership types have worked within an agency theory framework. It is found that different ownership types affect the relationship between corporate governance practices and corporate performance differently (Lappalainen \& Niskanen 2012). Ownership types, for the purpose of this paper, have been identified based on the direct and indirect voting rights with a cut off value of 20 per cent and consequently, this paper identified two ownership types, namely, widely held and closely held (La Porta et al. 2000, Klein, Shapiro \& Young 2005). Since the board of directors plays a pivotal role in corporate governance, this paper focuses principally on the board structure and the board functions to understand corporate governance practices (Mayer 1997, Krafft et al. 2013). 
As indicated in the literature review, the principal and agent model introduced by Jensen and Meckling (1976) suggests that corporate governance issues arise due to the separation of ownership and management. Corporate governance is concerned with ways of bringing the interests of the two parties in line with each other and ensuring that firms are run for the benefit of investors (Mayer 1996). The firms' ownership structure is a primary determinant of the extent of agency problems (Lemmon \& Lins 2003). As found in the literature, corporate governance systems vary according to the ownership structure of the organization, and the extant literature suggests that widely-held firms are governed better than closely-held firms. Klein, Shapiro and Young (2005) report that family firms, a form of closely-held firms, do not show much compliance to governance practices.In addition, Wei and Geng (2008) suggest that in China, the heavily concentrated equity ownership in the hands of large state-owned shareholders results in a less effective corporate governance mechanism. Furthermore, Hermalin (2005) finds a negative relationship between the composition of the board and concentrated managerial ownership. Based on the findings of these studies, the following hypothesis is proposed and tested in this study.

H1: Ownership concentration in terms of ownership type is negatively associated with the degree of compliance with corporate governance best practices pertaining to the board of directors.

This proposed relationship is graphically shown in Figure 1.

\section{Figure 1: Conceptual Model}

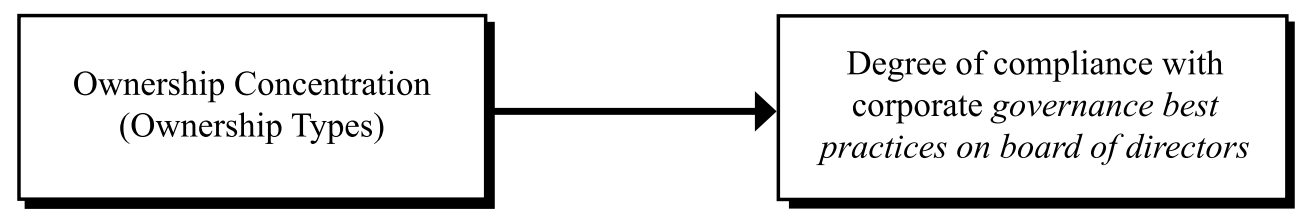

\section{Methodology}

\section{Sample and Data}

The population of the study is the 293companies listed in the CSE at the end of November 2014 representing twenty industry sectors. The sample was drawn from the best representation of the population to ensure more generalized results. The unit of analysis was a firm-year. The present study was based on secondary data, which is based on the annual reports downloaded from the CSE website-www.cse.lk. In selecting the sample, companies that were listed 
during the sample period were excluded. Financial institutions were also excluded from the sample as their unique financial structure makes them often subject to special rules and regulatory requirements, which are different from those of other sectors (Liang, Huang \& Lin 2011, Bauwhede 2009). Hence, the total number of companies that qualified for the sample selection was 208 of which a sample of 52 companies was selected. Firstly, the qualified companies were divided into three categories: large, medium and small, based on their market capitalization. Then, seventeen (17) companies were selected from each category. The sample period was five years, from 2009-2013. As a result, two hundred and sixty (260) firm-year data was available for the analysis. The selected sample companies are represented by fourteen sectors as shown in Table 1 below.

\section{Table1: Sector composition}

\begin{tabular}{lccr}
\hline Sector & $\begin{array}{c}\text { Number of } \\
\text { firms }\end{array}$ & $\begin{array}{c}\text { Number of } \\
\text { firm-years }\end{array}$ & \% \\
\hline Chemicals and Pharmaceuticals & 01 & 05 & 1.9 \\
Diversified & 07 & 35 & 13.5 \\
Food, Beverage and Tobacco & 07 & 35 & 13.5 \\
Footwear and Textiles & 02 & 10 & 3.8 \\
Hotels and Tourism & 10 & 50 & 19.4 \\
Health & 02 & 10 & 3.8 \\
Land and Property & 01 & 05 & 1.9 \\
Manufacturing & 08 & 40 & 15.4 \\
Oil Palms & 01 & 05 & 1.9 \\
Power and Energy & 02 & 10 & 3.8 \\
Plantation & 05 & 25 & 9.7 \\
Stores and Supplies & 02 & 10 & 3.8 \\
Telecommunication & 02 & 10 & 3.8 \\
Trading & 02 & 10 & 3.8 \\
Total & $\mathbf{5 2}$ & $\mathbf{2 6 0}$ & $\mathbf{1 0 0 . 0}$ \\
\hline
\end{tabular}

\section{Definitions of Variables and Measures}

\section{Ownership concentration}

Ownership concentration is operationalized using ownership types for the purpose of this study; and based on the extant literature the ownership types are identified based on direct and indirect voting rights with a cut off value of 20 per cent (La Porta et al. 2000, Klein, Shapiro \& Young 2005). Consequently, this study identified two ownership types: widely- 
held and closely-held (La Porta et al. 2000, Klein, Shapiro \& Young 2005, Senaratne \& Gunaratne 2008). Accordingly, a company with a shareholder with voting rights of 20 per cent or moreis classified as a closely-held company, and otherwise it is classified as widelyheld for the purposes of this study. The ownership data was derived from the annual reports of sample companies and their parent companies during the period 2009-2013. When the controlling shareholder of a company is another company, the shareholding of the latter was analyzed, which is the chain of control, to identify whether the former is widely held or not (La Porta, Shleifer \& Da Silanes 2000). For analytical purposes, the ownership concentration is operationalized as a dichotomous (dummy) variable (ownership), which is denoted as ' 1 ' for closely-held companies and ' 0 ' for widely-held firms.

\section{Degree of compliance with corporate governance practices}

Corporate governance information pertaining to the board of directors is obtained from the annual reports of sample companies for the period 2009 to 2013. Since the board of directors plays a pivotal role in corporate governance, the paper used an index to measure corporate governance constructed using the following corporate governance characteristics: board size, number of independent directors, number of board meetings, percentage of board attendance, CEO-Chair duality, audit committee independence and remuneration committee independence (Azim 2012, Black, Jang \& Kim 2006, Love 2010, Krafft et al. 2013, Villalongaa \& Amitb 2004). In this study, the approach to scoring items is essentially dichotomous, with a score of one (1) assigned to an item if it satisfies the condition (i.e., presence of the required board characteristic) and a score of zero (0) if it does not. The total score $C G_{I N D E X}$ for a company is:

\section{Equation 1: Corporate Governance Index}

$$
C G_{I N D E X}=\sum_{i=1}^{n} d_{i}
$$

Where $\boldsymbol{d}_{\boldsymbol{i}}$ is ' 1 ' if the item $\mathrm{i}$ is disclosed and ' 0 ' otherwise; $n$ is the maximum number of items.

\section{Control variables}

This paper used financial leverage, firm age industry/sector and total assets as control variables of the analysis in line with the extant literature. In the extant literature, these variables are used due to their control effect on the association between the ownership type and the degree of compliance with corporate governance best practices; and the findings of 
these studies indicate mixed results. Financial leverage was measured as a proportion of total debt to equity of the company (Klein, Shapiro \& Young 2005). The firm age was measured by the number of years that a firm has existed since the date of establishment (Villalongaa $\&$ Amitb 2004). Likewise, different sector dummies (see Table 1) were added to each sector (Lappalainen \& Niskanen 2012) and the natural logarithm of total assets at the end of each respective period was used to measure the total assets of each company (Bauwhede 2009, Klein, Shapiro \& Young 2005, Azim 2012).

\section{Strategy for Analysis}

\section{Panel data analysis}

Green (2008) states that panel data analysis is the appropriate data analysis method for a study of this nature as it uses both cross-sectional and time-series data. Furthermore, panel data is described as data collected for individual units observed over a considerable period (Gujarati 2003, Hsiao 2003). Panel data analysis is one of the most efficient statistical methods available and widely used in econometrics, social science and epidemiology (Maddala 1986). Moreover, several terms have been used to describe panel data including pooled and longitudinal data, event study and cohort analysis (Gujarati 2003) using Stata, which is a widely used statistical package useful in programs for panel data analysis (Gujarati 2003).

\section{Model}

To test the relationship between ownership concentration in terms of ownership type and degree of compliance with corporate governance practices pertaining to the board of directors including the control variables mentioned above, the following model was used:

$$
C G_{\text {INDEX }}=\alpha+\beta_{1} \text { Ownership }+\beta_{2} \text { Lever }+\beta_{3} \text { Age }+\beta_{4} \operatorname{Sec}+\beta_{5} \operatorname{LnTA}+\varepsilon
$$

Where: $C G_{\text {INDEX }}=$ Corporate Governance Index; Ownership = Ownership Types; Lever = Financial Leverage; Age = firm age; $S e c=$ Sector; $L n T A=$ natural log of total assets, "which were defined in the Section on 'Definitions of variables and measures' above. 'In the next section, the results of the analysis suggested in this section are presented.

1 The data has been winsorised at the 0.05 level to make sure that outliers do not affect the data analysis. 
Ownership Concentration and Degree of Compliance with Corporate Governance Best Practices of Public Listed Companies in Sri Lanka

\section{Analysis and Discussion}

Table 2 provides the characteristics of the sample in terms of descriptive statistics of the dependent and independent variables used in this study.

Table 2: Characteristics of the sample

\begin{tabular}{lcrrrrrrr}
\hline Variable $^{*}$ & N & Mean & Max & Min & \multicolumn{1}{c}{ SD } & p25 & p50 & p75 \\
\hline CG $G_{\text {INDEX }}$ & 260 & 4.11 & 6.00 & 1.00 & 1.16 & 3.00 & 4.00 & 5.00 \\
Ownership & 260 & 0.79 & 1.00 & 0 & 0.41 & 1.00 & 1.00 & 1.00 \\
LEVERAGE & 260 & 0.55 & 1.32 & 0.02 & 0.42 & 0.16 & 0.50 & 0.90 \\
AGE & 260 & 38.68 & 99.00 & 9.00 & 26.19 & 19.00 & 30.00 & 59.00 \\
LnTA & 260 & 7.28 & 1.15 & 9.75 & 5.62 & 6.43 & 6.92 & 7.91 \\
\hline
\end{tabular}

"Note: The definitions of the variables are indicated in the sub-section, 'Definitions of variables and measures'.

In terms of $C G_{\text {INDEX }}$ which is based on compliance with corporate governance best practices pertaining to board characteristics, Table 2 indicates that the maximum value is 6 and the minimum is 1 , and the mean value of this index is 4.11 . Based on this mean value, it could be observed that the overall compliance level is $58.71 \%$ (i.e., 4.11 divided by the maximum achievable index value of 7). Furthermore, the median value of 4.00 shows that fifty percent of the companies have achieved a $C G_{I N D E X}$ of four or less. However, the standard deviation of this index is 1.16 .

The mean value of variable: Ownership is 0.79 which shows that the majority of the sample companies are closely-held (precisely, forty out of fifty two companies in the sample are closely-held). The analysis of the data further indicates that these closely-held companies have major shareholders representing an individual, a few closely connected individuals or a family. On the other hand, only $21 \%$ of the sample companies are widely-held. La Porta et al. (2000) found that in developing economies, ownership is heavily concentrated and only $36 \%$ of the companies in such countries are widely-held. In addition, in New Zealand, which is also considered an emerging market, only $30 \%$ of companies can be classified as widelyheld. Furthermore, Claessens and Fan (2003) state that one or several members of a family hold tightly onto the shares of a typical Asian corporation. 
NSBM Journal of Management

Vol. 1, No. 1, January - June, 2015

Table 3: Summary of correlations

\begin{tabular}{lcccc}
\hline & Ownership & CG $_{\text {INDEx }}$ & LEVERAGE & AGE \\
\hline Ownership $^{*}$ & 1.000 & & & \\
CG $G_{I N D E X}$ & $-0.421^{* * *}$ & 1.000 & & \\
LEVERAGE & 0.038 & -0.032 & 1.000 & \\
$A G E$ & -0.041 & 0.055 & 0.012 & 1.000 \\
\hline
\end{tabular}

*Note: The definitions of the variables are indicated in the sub-section, 'Definitions of variables and measures'.

${ }^{*} p<0.10,{ }^{* *} p<0.05,{ }^{* * *} p<0.01$

Table 3 presents Spearman's correlation for all the variables in the study. Ownership concentration (Ownership) in terms of ownership types shows a significant negative relationship with the degree of compliance to corporate governance best practices pertaining to board characteristics, $\left(C G_{I N D E X}\right)$ at a confidence level of $99 \%$, as hypothesized in the conceptualization of this paper. The multivariate panel data regression analysis and results are discussed next.

According to the methodology discussed in this paper, the multivariate panel data regression analysis was used to identify the association between ownership concentration in terms of ownership types and the degree of compliance with corporate governance best practices pertaining to the board of directors. Table 4 depicts the results of this analysis.

Table 4: Panel data analysis results: Ownership type and corporate governance

\begin{tabular}{lc}
\hline & $C G_{I N D E X}$ \\
\hline Ownership $^{*}$ & $-1.067^{* * *}$ \\
LEVERAGE & 0.049 \\
AGE & -0.002 \\
LnTA & $0.327^{* * *}$ \\
Constant & $3.241^{* * *}$ \\
Observations & 260 \\
${\text { Overall }{ }^{2}}^{2}$ & 0.3843 \\
Wald chi $^{2}$ & 41.02 \\
Model Sig. & 0.006 \\
\hline
\end{tabular}

${ }^{*} p<0.10,{ }^{* *} p<0.05,{ }^{* * *} p<0.01$

"Note: The definitions of the variables are indicated in the sub-section, Definitions of variables and measures'. The coefficients pertaining to Sector and Year dummies are not depicted. 
As shown in Table 4, the results support the hypothesized negative relationship between ownership concentration in terms of ownership types (Ownership) and degree of compliance with corporate governance practices pertaining to the board of directors (CG_INDEX). Hence, the study finds that widely-held firms are more governed in terms of accepted governance practices than closely held firms. This finding is in line with several studies that have previously dealt with the relationship between different dimensions of corporate governance and ownership concentration. Klein, Shapiro and Young (2005) report that family firms in Canada, a form of closely-held firms, showed less compliance with governance practices. In addition, in China, the heavily concentrated equity ownership in the hands of large stateowned shareholders gives rise to a less effective corporate governance mechanism in Chinese companies (Wei \& Geng 2008). Further, Hermalin (2005) found a negative relationship between the composition of the board and managerial ownership.

\section{Conclusion}

This paper examined the association between ownership concentration in terms of ownership types and degree of compliance with corporate governance best practices pertaining to the board of directors of Sri Lankan public listed companies. A negative association was hypothesized between these two constructs in the study. The findings of this study reveal a high level of concentration of ownership in most Sri Lankan public listed companies with the presence of a controlling shareholder. The major shareholders of these companies are represented by an individual, a few closely connected individuals or a family. The findings of the multivariate panel date regression analysis indicate that the concentrated ownership structure has a significant negative association with compliance to corporate governance best practices relating to the board of directors. These findings highlight the need for Sri Lankan companies to formulate an optimal ownership structure to improve corporate governance practices, which in turn would lead to the eradication of possible malpractices such as corruption, fraud and misappropriation of resources to ensure long-term sustainability. Hence, policy makers and regulators such as SEC, CA Sri Lanka, and the Central Bank of Sri Lanka can draw insights from the findings of this study in making corporate governance reforms in relation to minority protection and other related areas in developing an appropriate corporate governance structure for public listed companies in the wider society and preventing financial scandals which are likely to occur due to lack of good governance practices.

However, this study has certain limitations. Firstly, the scope of the study was limited to 52 listed companies in Sri Lanka. Therefore, future researchers can expand the study by using a larger sample of companies. In addition, the current study used only a five-year time span 
from 2009 to 2013, which can also be expanded. Secondly, from a corporate governance point of view, the study considered the compliance only in terms of board characteristics (including audit committee independence and remuneration committee independence). Therefore, other aspects of corporate governance can also be incorporated in future research. Finally, this study excludes companies in the banking and financial sectors like banks, finance companies, leasing companies, insurance companies, investment companies and fund management companies due to their unique corporate governance regulations. Therefore, it would be useful if future researchers undertake studies on those companies as well and focus on sectorwise studies separately to further explore the relationships studied in this paper.

\section{References}

Azim, MI 2012, 'Corporate governance mechanisms and their impact on company performance: a structural equation model analysis', Australian Journal of Management, vol. 20, no. 4, pp. 481-505.

Barton, L 2007, 'Reflections on the legitimacy of regional environmental governance: lessons from Australia's experiment in natural resource management', Journal of Environmental Policy \& Planning, vol. 10 , no. 1 , pp. 1-30.

Bauwhede, HV 2009, 'On the relation between corporate governance compliance and operating performance', Accounting and Business Research, vol.39, no.5, pp. 497-513.

Black, BS, Jang, H \& Kim, W 2006, 'Does corporate governance predict firms market values? evidence from Korea', The Journal of Law, Economics, \& Organization, vol. 22,no. 2, pp. 366-413.

Bokpin, GA 2013,'Ownership structure, corporate governance and bank efficiency: an empirical analysis of panel data from the banking industry in Ghana', Corporate Governance: The International Journal of Business in Society, vol. 13,no. 3, pp. 274-287.

Bokpin, GA, Isshaq, Z \& Otchere, FA 2011, 'Ownership structure, corporate governance and corporate liquidity policy: evidence from the Ghana Stock Exchange', Journal of Financial Economic Policy, vol. 3,no. 3, pp. 262-279.

Cadbury, A 1992, The financial aspects of corporate governance, Gee and Co. Ltd., London.

Cazurra, CA \& Aguilera, RV 2004, 'Codes of good governance worldwide: what is the trigger?', Organization, vol. 25,no. 3, pp. 415-443.

Charkham, J \& Simpson, A 1999, Fair shares: the future of shareholder power and responsibility, Oxford University Press, Oxford.

Claessens, S \& Fan, J 2003, 'Corporate governance in Asia: a survey', International Review of Finance, vol. 57 , no. 6 , pp. $2741-2771$.

Clarke, T 2014, 'Dangerous frontiers in corporate governance', Journal of Management \& Organization, vol. 26 , no. 1 , pp. $268-286$.

Connelly, BL, Hoskisson, RE, Tihanyi, L \& Certo, T 2010,'Ownership as a form of corporate governance', Journal of Management Studies, vol. 47,no. 8, pp. 1561-1589. 


\section{Ownership Concentration and Degree of Compliance with Corporate Governance Best Practices of Public Listed Companies in Sri Lanka}

Fama, EF \& Jensen, MC 1983, 'Separation of ownership and control', Journal of Law and Economics, vol. 26,no. 2, pp. 301-325.

Gollakota, K \& Gupta, V 2006, 'History, ownership forms and corporate governance in India', Journal of Management History, vol. 12,no. 2, pp. 185-198.

Green, WH 2008, Econometric analysis 6th edn, Prentice Hall, Upper Saddle River, N.J.

Greenwood, R, Deephouse, DL \& Li, SX 2007, 'Ownership and performance of professional service firms’, Organization Studies, vol. 28,no. 2, pp. 219-238.

Guest, PM 2010, 'Board structure and executive pay: evidence from the UK', Cambridge Journal of Economics, vol. 34,no. 6, pp. 1075-1096.

Gujarati, D 2003, Basic econometrics, 4th edn, McGraw Hill Publishing,New York.

Haat, MH, Rahman, RA \& Mahenthiran, S 2008, 'Corporate governance,transparency and performance of Malaysian companies', Managerial Auditing Journal, vol. 23,no. 8, pp. 744-778.

Hart, O 1995, 'Corporate governance: some theory and implications', The Economic Journal, vol. 105,no. 430, pp. 678-689.

Heenatigala, K 2011, Corporate governance practices and firm performance of listed companies in Sri Lanka (Doctoral dissertation), Victoria Law School,Victoria University, Melbourne.

Hermalin, BE 2005, 'Trends in corporate governance', Journal of Finance, vol. 60,no. 5, pp. 23512384.

Hsiao, C 2003, Analysis of Panel Data, 2nd edn, Cambridge University Press, Cambridge, United Kingdom.

Isshaq, Z, Bokpin, GA \& Onumah, JM 2009, 'Corporate governance, ownership structure, cash holdings, and firm value on the Ghana stock exchange', The Journal of Risk Finance, vol. 10, no. 5, pp. 488-499.

Jensen, MC 1998, Foundations of organizational strategy, Harvard University Press, Cambridge.

Jensen, M \& Meckling, WH 1976, 'Theory of the firm: managerial behavior, agency costs, and ownership structure', Journal of Financial Economics, vol. 3,no. 4, pp. 305-360.

Kaur, P \& Gill, S 2008, The effects of ownership structure on corporate governance and performance: an empirical assessment in india (Research Project), University Business School, Panjab University, Panjab.

Klein, P, Shapiro, D \& Young, J 2005, 'Corporate governance, family ownership and firm value: the Canadian evidence', Corporate Governance: An International Review, vol. 13, no. 6, pp.769-784.

Krafft, J, Qu, Y, Quatraro, F \& Ravix, JL 2013, 'Corporate governance, value and performance of firms: new empirical results on convergence from a large international database', Industrial and Corporate Change, vol. 23, no. 2, pp. 361-397.

La Porta, R, De-Silanes, FL, Shleifer, A \& Vishny, R 2000, 'Investor protection and corporate governance', Journal of Financial Economics, vol. 54 , no. 2, pp. 471-517.

Lappalainen, J, \& Niskanen, M 2012, 'Financial performance of SMEs: impact of ownership structure and board composition', Management Research Review, vol. 35, no. 11, pp. 1088-1108. 


\section{NSBM Journal of Management}

Vol. 1, No. 1, January - June, 2015

Lemmon, ML \& Lins, KV 2003, 'Ownership structure, corporate governance,and firm value: evidence from the East Asian financial crisis', The Journal of Finance, vol. 58, no. 4, pp. 1445-1468.

Liang, CJ, Huang, TT \& Lin, WC 2011, 'Does ownership structure affect firm value? intellectual capital across industries perspective', Journal of Intellectual Capital, vol. 12,no. 4, pp. 552-570.

Love, I 2010, 'Corporate governance and performance around the world: what we know and what we don't', The World Bank Research Observer, vol. 26,no. 1, pp. 42-70.

Lubatkin, MH, Lane, PJ, Collin, SO \& Very, P 2005, 'Origins of corporate governance in the USA,Sweden and France', Organization Studies, vol. 26,no. 6, pp. 867-888.

Maddala, GS 1986, Limited-dependent and qualitative variables in econometrics. Cambridge University Press, Cambridge, United Kingdom.

Mayer, C 1997, 'Corporate governance, competition, and performance', Journal of Law and Society, vol. 5 , no. 2, pp.152-76.

Mollah, S, Farooque, OA \& Karim, W 2012, 'Ownership structure, corporate governance and firm performance: evidence from an African emerging market', Studies in Economics and Finance, vol. 29,no. 4, pp. 301-319.

Monks, RA \& Minow, N 1995, Corporate Governance. Blackwell Publishing Ltd, Victoria.

Mwanja, BK, Marangu, WN, Wanjere, DM \& Thuo, KJ 2014,'Effect of corporate governance on performance of savings and credit co-operative societies in Kakamega County', European Journal of Business and Management, vol. 6,no. 30, pp. 123-136.

Rezaee, Z 2009, ‘Corporate governance and ethics', The International Journal of Accounting, vol. 20, no. 1 , pp. 306-307.

Senaratne, S \& Gunaratne, PSM 2008, 'Corporate governance development in Sri Lanka: prospects and problems', proceedings of International Research Conference on Management and Finance, 2008, University of Colombo, pp. 79-89.

Shleifer, A \& Vishny, RW 1997, 'A survey of corporate governance', Journal of Finance, vol. 52,no. 2, pp. 737-783.

Stiles, P \& Taylor, B 1993, 'The failure of corporate governance', Corporate Governance: An International Review, vol. 1, no. 1, pp.34-45.

Tuan, LT 2014, 'Corporate governance and brand performance', Management Research Review, vol. 37, no. 1, pp. 45-68.

Villalongaa, B \& Amitb, R 2004, 'How do family ownership, control and management affect firm value', Journal of Financial Economics, vol. 80 , no. 5, pp. 385-417.

Wei, G, \& Geng, M 2008, 'Ownership structure and corporate governance in China: some current issues’, Managerial Finance, vol. 34,no. 12, pp. 934-952.

Zeitun, R, \& Tian, GG 2007, 'Does ownership affect a firm's performance and default risk in Jordan?', Corporate Governance: The International Journal of Business in Society, vol. 7, no. 1, pp. 66-82. 